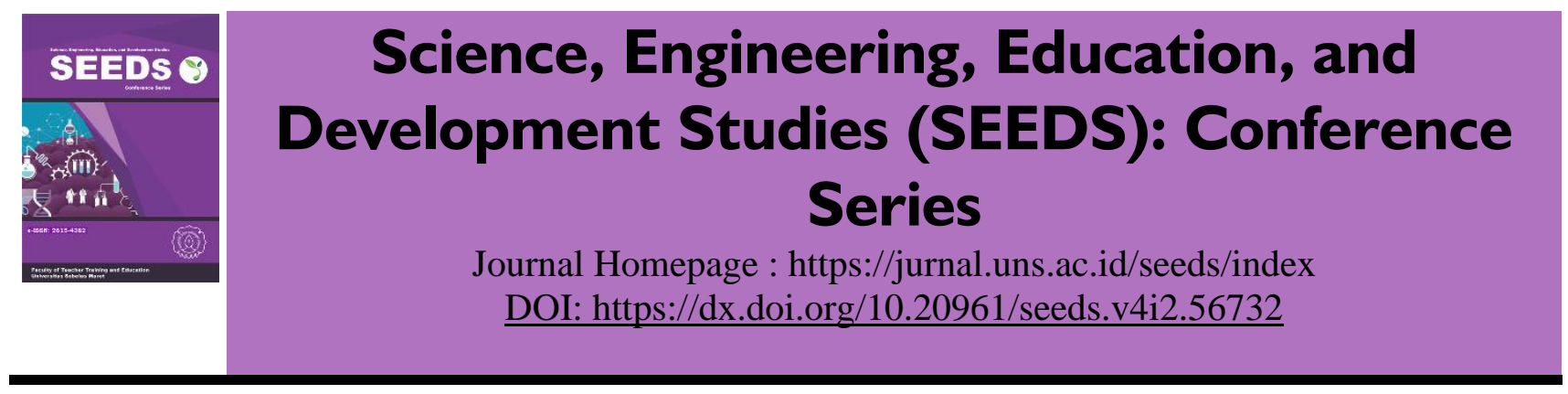

\title{
DAMPAK TEKNOLOGI INFORMASI BAGI SISWA-SISWI SMP KARTIKA 1-7 PADANG
}

\author{
Rini Permata Sari
}

SMP Kartika 1-7 Padang, Indonesia

*Correspondence: rinipelangi20578@gmail.com

Article Info :

Available online 24 Nopember 2020

\section{Keywords:}

kecerdasan informasi,

kecerdasan intelektual,

kecerdasan emosional,

kecerdasan mental, kecerdasan social.

\begin{abstract}
The use of information technology (IT) has positive and negative effects depending on the ability of users to use it, including children. Intelligence in the use of information technology has a very large influence on the formation of children's mental abilities and will affect the level of intelligence of children. Parents have a role to be able to know about the changes that occur in the growth and development of children. Changes that occur in children after using information technology and whether the influence of information technology has a positive or negative effect on children's intelligence levels include intellectual, emotional, spiritual and social terms

The impact of information technology greatly affects the behavior and attitudes of students because there is a direct relationship in the use of information technology. The purpose of our discussion is to discuss the impact of engineering and technology in meeting student needs. Where students can rationally use information technology. students can uncover the positive and negative impacts of information technology.

Keywords: information intelligence, intellectual intelligence, emotional intelligence, mental intelligence, social intelligence..
\end{abstract}




\section{PENDAHULUAN}

Perkembangan teknologi semakin modern dan cepat, dan tidak semua orang dapat menghindari kemajuan teknologi. Teknologi mencakup semua aspek kehidupan, teknologi lahir untuk memudahkan manusia dalam bekerja. Teknologi informasi adalah bidang teknologi yang paling cepat berkembang saat ini. Teknologi informasi (TI) adalah istilah umum untuk merujuk pada teknologi apa pun yang membantu orang membuat, memodifikasi, menyimpan, mengomunikasikan, dan menyebarkan informasi.

Komputer menggabungkan komputasi dan komunikasi berkecepatan tinggi untuk data, suara, dan video. Perkembangan teknologi informasi telah menciptakan cara hidup baru dalam masyarakat, dari awal hingga akhir kehidupan, yaitu kehidupan ini dipengaruhi oleh banyak huruf yang diawali dengan awalan 'e', seperti e-commerce, e-government, e-learning, e-library, e-journal, e-medicine, e-lab, dan sebagainya.

Ananta Sannai (Rusman, 2011: 88) mendefinisikan teknologi informasi dan komunikasi (TIK) sebagai sarana atau alat untuk perolehan pengetahuan di antara manusia.

Kemajuan TIK membuat sektor pendidikan sangat perperan penting. Keberadaan internet dan perangkat komputer modern menjadi solusi kegiatan belajar mengajar dalam rangka pandemi Covid-19. Dengan menggunakan berbagai software aplikasi konferensi pada komputer atau smartphone yang didukung dengan akses internet, pembelajaran tetap dapat berlangsung meskipun terdapat kendala di dalam kelas.

Penyalahgunaan IT oleh siswa sering terjadi karena siswa masih belum mampu memasukkan IT ke dalam kehidupannya, dimana terdapat pornografi dan kurangnya minat sosialisasi siswa

\section{KAJIAN PUSTAKA}

Mempelajari teknologi informasi Teknologi memiliki pengaruh yang besar bagi masyarakat modern, hampir sebagian besar kehidupannya.Ketergantungan mereka pada informasi, Nana Syaodih Sukmadinata (2002) berpendapat bahwa teknologi telah ada sejak zaman dahulu atau manusia telah menggunakan teknologi tersebut. Jika orang zaman dahulu memecahkan biji dengan batu atau memetik buah dengan galah, sebenarnya mereka menggunakan teknologi, yaitu teknologi sederhana. Sejak zaman manusia menciptakan dan menggunakan teknologi dari waktu ke waktu, terus berkembang hingga sekarang. Teknologi informasi, atau teknologi informasi dalam bahasa Inggris, adalah istilah umum yang mengacu pada teknologi apa pun yang membantu orang membuat, memodifikasi, menyimpan, mengomunikasikan, dan menyebarkan informasi. Komputer mengumpulkan 4.444 perhitungan dan komunikasi berkecepatan tinggi untuk data, suara, dan video. Contoh teknologi informasi tidak hanya komputer pribadi, tetapi juga telepon modern, peralatan rumah tangga, dan perangkat seluler seperti telepon seluler.

Dalam konteks bisnis, American Information Technology Association menjelaskan pemrosesan lokal, penyimpanan, dan penyebaran informasi visual, teks, dan digital melalui mikroelektronika berdasarkan kombinasi komputasi mesin dan telekomunikasi. Istilah dalam pengertian modern pertama kali muncul dalam artikel tahun 1958 yang diterbitkan oleh Harvard Business Review, di mana penulis Leavitt dan Whisler (1958) mengamati bahwa "teknologi baru masih belum memiliki nama". Kami akan menyebutnya Teknologi Informasi (TI). "Beberapa bidang teknologi informasi yang modern dan muncul adalah teknologi web generasi mendatang, bioinformatika, komputasi awan, sistem informasi global, basis pengetahuan skala besar, dan bidang keahlian lainnya. Lainnya

Hedi Sasrawan (2012) Dunia telah berubah dan berkembang dengan sangat cepat. Perkembangan ilmu pengetahuan juga berkembang seperti badai. Sekarang perbatasan dunia tampaknya tidak terlihat. Semuanya bisa kita lakukan dengan cepat, akurat dan murah. Kemajuan teknologi saat ini tidak dapat dipisahkan dari kehidupan manusia.

Peran teknologi informasi Dalam kehidupan modern, teknologi informasi adalah bidang yang paling dominan, siapa yang menguasai teknologi ini akan menjadi pemimpin dunia mereka, teknologi informasi memiliki banyak peran, peran di berbagai bidang mulai dari pendidikan, industri, kesehatan, pemerintahan, dll.

Menurut Prasojo (2011:4), teknologi informasi diartikan sebagai ilmu pengetahuan dalam bidang informasi yang berbasis komputer dan perkembanganya sangat pesat. Teknologi Informasi sebagai media pendidikan dilakukan dengan menggunakan mediamedia komunikasi seperti telepon, komputer, internet, email, dan sebagai berikut. Interaksi antara dosen dan mahasiswa tidak hanya dilakukan melalui hubungan tatap muka tetapi juga dilakukan dengan menggunakan mediamedia tersebut. 
Teknologi komunikasi adalah media fisik dalam struktur organisasi yang mengandung nilai-nilai sosial, memungkinkan setiap individu untuk mengumpulkan, mengolah,

dan saling bertukar informasi. Yang mendasari sesuatu yang dapat digolongkan sebagai teknologi komunikasi adalah: pertama Teknologi komunikasi dapat diimplementasikan dalam suatu alat. Kedua, teknologi komunikasi muncul dari struktur sosial, ekonomi dan politik. Ketiga, teknologi komunikasi menambah nilai pada struktur ekonomi, sosial dan politik tertentu.

Sedangkan teknologi komunikasi meningkatkan indera manusia terutama kemampuan mendengar dan melihat Hedi Sasrawan (2012) Dunia telah berubah dan berkembang sangat pesat. Perkembangan ilmu pengetahuan juga berkembang seperti badai. Sekarang perbatasan dunia tampak tidak terlihat. Semuanya bisa kita lakukan dengan cepat, akurat dan murah. Kemajuan teknologi saat ini tidak dapat dipisahkan dari kehidupan manusia. Berbagai informasi yang terjadi di berbagai belahan dunia kini tersedia langsung bagi kami. Tentunya kemajuan teknologi ini telah menyebabkan perubahan besar dalam kehidupan masyarakat dengan segala peradaban dan budayanya.

Perubahan ini juga berdampak besar pada transformasi nilai yang ada. Akibatnya, segala informasi baik yang bernilai positif maupun negatif, dapat dengan mudah di akses. Dan di akui atau tidak, perlahanlahan mulai mengubah pola hidup dan pola pemikiran khususnya masyarakat pedesaan dengan segala image yang menjadi ciri khas mereka. Suatu karakteristik individu seperti Ditinjau dari kondisi sosial ekonomi, perilaku komunikasi dan interaksi, perilaku menerima inovasi dibedakan menjadi 5 jenis, yaitu early adopter, innovator, early Majority, Late Major dan Late Adopter sebagaimana dikatakan oleh Rogers (2003) dalam Suharti, (2013).

Dengan adanya teknologi informasi sangat memudahkan siswa dalam melakukan suatu inovasi dan kreasi dalam berbagai hal.

Kreativitas pada dasarnya adalah kemampuan umum untuk menciptakan sesuatu yang baru, seperti kemampuan untuk memberikan ide-ide baru yang dapat diterapkan pada pemecahan masalah, atau kemampuan untuk melihat hubungan baru antara item yang sudah ada sebelumnya (Munandar, 2004: 25).

Hubungan antara perubahan sosial dan perkembangan teknologi komunikasi Perubahan terjadi dalam kehidupan masyarakat, perubahan ini tidak akan pernah terjadi Anda bukan Google? dicegah karena dengan sendirinya akan selalu mengikuti arus perubahan yang terjadi. Perubahan sosial sedang berlangsung, salah satunya karena teknologi seperti televisi dan komputer (Internet) mengumpulkan informasi di bidang politik, ekonomi dan ilmiah. Seperti dilansir Rogers (1986: 110) "Penyebab dan akibat dari perubahan sosial adalah teknologi komunikasi." Menurut Rogers, dapat disimpulkan bahwa perubahan sosial yang terjadi pada tahun disebabkan oleh teknologi yang semakin maju.Kemajuan telah terjadi sesuai dengan tatanan kehidupan sosial. dengan kemajuan teknologi masyarakat akan lebih mudah dalam mengakses informasi walaupun dari jarak jauh sehingga komunikasi dalam hal ini tidak dibatasi oleh ruang dan waktu, masyarakat mengakses informasi di seluruh dunia semakin mudah membuat dunia ini terasa sempit dengan kemajuan teknologi saat ini,

Teknologi komunikasi lebih berpengaruh pada anak kecil dibandingkan anak kecil dan orang tua. mungkin karena anak muda suka melakukan hal baru dan suka tantangan untuk berubah. misalnya, efek televisi dan komputer tersebar luas saat ini. Penyebab dan akibat dari perubahan sosial adalah teknologi komunikasi. Perkembangan sistem informasi dan database yang sangat besar telah menyebabkan akumulasi informasi yang sangat berguna untuk lingkungan politik, ekonomi dan ilmiah. Teknologi komunikasi memainkan peran penting dalam implementasi kebijakan budaya dan berkontribusi pada demokratisasi budaya melalui cara penyebaran informasi yang lebih cepat diterima oleh publik. Setiap perubahan sosial memiliki dampak dan teknologi memainkan peran penting. Apa dampak dari teknologi komunikasi?

Teknologi komunikasi juga memiliki kekuatan untuk mengubah kondisi sosial, perubahan sosial dimungkinkan selama perubahan tersebut didasarkan pada hukum, nilai-nilai etika dan tidak bertentangan dengan budaya di Indonesia. Perubahan sosial terjadi sebagai akibat dari interaksi sosial.

Salah satu hal yang dapat kita ketahui adalah bahwa teknologi komunikasi berkembang cukup pesat dan mempengaruhi sikap kita terhadap kehidupan sosial. Misalnya, Internet adalah teknologi yang tidak terpisahkan bagi kaum muda. Hidup yang berjalan saat ini sepertinya tidak seperti itu. Karena itu kecenderungan seseorang untuk ingin tahu tentang hal-hal baru. Otomatis saat siswa masih dihitung? siswa ilmu komputer akan lebih kaya informasi. Sehingga informasi ini dapat membawa siswa pada perubahan social. Menurut Suyanto: Teknologi informasi dan komunikasi adalah sarana/alat yang digunakan untuk mengirimkan data, untuk memperoleh data/informasi, atau untuk memberikan informasi kepada orang lain, dan dapat digunakan untuk keperluan lain. 
Jadi dapat disimpulkan bahwa sebenarnya setiap teknologi informasi berdampak pada perubahan sikap seseorang. Yang bias memberikan dampak positif dan negative.

Dampak Positif dan Negatif Teknologi Informasi Seiring perkembangan teknologi semakin cepat, akan lebih diuntungkan dengan teknologi informasi, dampak positif dari kemajuan teknologi informasi dapat penulis rangkum sebagai berikut:

1. siswa akan lebih cepat bertukar informasi sehingga lebih efektif dan efisien dalam bertukar informasi yang diperlukan.

2. Terwujudnya siswa informasi.

3. siswa yang memiliki kecerdasan luas.

4. Menjadikan siswa kreatif dan inovatif.

Mengenai dampak negatifnya:

1. Tampaknya ada degradasi etika pengguna yang tidak terkontrol.

2. Adanya cyber crime atau kejahatan dunia maya

3. Kurangnya minat pelajar di masyarakat

4. Kemudahan memperoleh pornografi

Suyanto (2005:10) teknologi informasi merupakan sebuah bentuk umum yang menggambarkan setiap teknologi yang membantu menghasilkan, memanipulasi, menyimpan, mengkomunikasikan, dan atau menyampaikan informasi.

Hampir setiap teknologi memiliki dua sisi dampak, positif dan negatif. Begitu juga dengan perkembangan teknologi komunikasi. Dampak positifnya karena teknologi komunikasi dapat mendorong lahirnya banyak inovasi baru yang memudahkan kehidupan masyarakat. Dampak negatif karena teknologi komunikasi mempengaruhi kehidupan sosial, dimana standar yang berlaku sering diabaikan dan sering terjadi kejahatan teknologi yang membahayakan masyarakat.

\section{KESIMPULAN}

Peran teknologi informasi dalam kehidupan tidak dapat dipisahkan Kita tidak menyadari bahwa kecepatan dan ketepatan teknologi informasi memiliki pengaruh yang besar, namun bagaimana kita menyikapi perkembangan teknologi informasi khususnya bagi pelajar di Indonesia selama 5-10 tahun kedepan?

Pesatnya perkembangan teknologi saat ini membawa banyak perubahan dalam kehidupan masyarakat. Tak terkecuali dalam hal interaksi manusia. Kemajuan teknologi membuat komunikasi menjadi lebih mudah. Saat kita tidak bisa bertatap muka, kita masih bisa berkomunikasi. Adanya sarana komunikasi seperti jejaring sosial dan aplikasi instant messaging yang dapat digunakan untuk chatting membuat smartphone banyak diminati kalangan anak muda khususnya remaja.

\section{DAFTAR PUSTAKA}

Leavitt, H., \& Whisler, T. (1958). Management in the 1980's in "Harvard Business Review”. VoL36, (6), $911-937$. Munandar, U. (2004). Pengembangan Emosi dan Kreativitas. Jakarta: Rineka Cipta.

Prasojo, L. D. (2011). Teknologi Informasi Pendidikan. Gava Media, Yogyakarta.

Rogers, Everett M. 1986. Communication Technology: The New Media in Society. New York: The Free Press.

Sasrawan, H. (2012). Sistem Pencernaan Pada Manusia. https://hedisasrawan.blogspot.com/2012/10/sistempencernaan-pada-manusia-materi_25.html

Suharti, S. (2013). Trends in education in Indonesia. In Education in Indonesia. Institute of Southeast Asian Studies (ISEAS).

Sukmadinata, N. S. (2002). Pengembangan kurikulum teori dan praktek.

Suyanto, M. (2005). Pengantar Teknologi Informasi Untuk Bisnis. Penerbit Andi. 
Science, Engineering, Education, and Development Studies (SEEDS): Conference Series Vol.4 no.2 (2020) 